\title{
Rethinking Japan's China Policy: Japan as an Accommodator in the Rise of China, 1978-2011
}

\author{
Björn Jerdén and Linus Hagström
}

\begin{abstract}
For the last four decades Sino-Japanese relations have been characterized by steadily growing economic and sociocultural interactions. Yet, greater interdependence has developed in tandem with bilateral tensions. Many analysts have attempted to explain the latter as a result of Japan trying to balance or contain the burgeoning growth of Chinese capabilities. In this article, we question and qualify this widespread understanding of Japan's response to China's rise by examining how Japan has handled China's rise between 1978 and 2011. More precisely, how has Japan dealt with China's long-term core strategic interests, which are embodied in the post-1978 Chinese "grand strategy" that is believed to have been instrumental to China's rise? Our main finding is that to a significant degree Japan has accommodated the rise of China rather than balanced against it. KeYwords: Sino-Japanese relations, Japan's China policy, the rise of China, containment, balancing, accommodation
\end{abstract}

"THE RISE OF CHINA" IS ONE OF THE MOST SPECTACULAR PROCESSES TO unfold in contemporary international relations. Ever since Deng Xiaoping introduced policies to reform and open up the People's Republic of China (PRC/China) in 1978, there has been a gradual and long-term, yet spectacular and historic, expansion of the country's economic, military, and political capabilities. The global ramifications of China's rise have already been enormous, and there are likely to be more such ramifications just beyond the horizon. Nowhere do the effects of China's transformation run as deep as in its own backyard. How to handle China's growing capabilities, and power, has been elevated to a core political issue throughout East Asia and the world - not least in Japan.

Japan and China normalized diplomatic relations in 1972. Six years later they signed a treaty pledging to "develop relations of perpetual peace and friendship" (Ministry of Foreign Affairs of Japan 1978). The 
relationship has since been characterized by steadily growing economic and sociocultural interactions. China has become Japan's most important trading partner and the primary destination for Japanese foreign direct investment (FDI), and Japan is conversely China's third-largest trading partner, its second-largest source of FDI, and one of the top destinations for Chinese studying abroad (International Monetary Fund 2010; Naughton 2007, 363).

Paradoxically, perhaps, Sino-Japanese interdependence has developed in tandem with increased bilateral tension in recent years. During Prime Minister Koizumi Junichiro's incumbency (2001-2006), the relationship was particularly strained, represented most importantly by Beijing's decision to discontinue bilateral summitry between October 2001 and September 2006 - in reaction to Koizumi's recurring visits to the Yasukuni Shrine in Tokyo, where fourteen Class A war criminals are commemorated. Public opinion polls in both countries also demonstrate that mutual perceptions grew increasingly negative in this period, reaching a historic low in the mid-2000s (Hagström 2008-2009). A significant number of observers have sought to explain mounting tensions in the bilateral relationship as a result of Japan "resisting" (Ross and Zhu 2008, 7), "containing" (Odgaard 2008, 193-194; Men 2008, 21), "balancing," or "constraining" (Chung 2009, 663, 669) China's rise, either by beefing up its indigenous defense capability (internal balancing) or by strengthening the alliance with the United States (external balancing).

Although realists of different stripes tend to disagree about the likelihood that balancing behavior will occur in a given situation, at least some strands of balance-of-power theory predict Japanese balancing against China's rise to prevent the neighbor from becoming too powerful in East Asia (cf. Mearsheimer 2001, 140-143, 156-157). Kenneth Waltz, who regards balance of power as the hard core of neorealist theory, has repeatedly hypothesized that Japan's China policy would develop along exactly these lines. In 1993, he wrote, "Any country in Japan's position is bound to become increasingly worried about its security, the more so because China is rapidly becoming a great power in every dimension: internal economy, external trade, and military capability" (Waltz 1993, 68). Waltz has since anticipated that Japan would respond to growing Chinese power by developing a nuclear deterrent capability and upgrading its conventional military capabilities: "The presence of China's ample nuclear forces, combined with the drawdown of American military forces, can hardly be ignored by Japan" (Waltz $2000,33)$. He has also predicted that the course of China's rise will 
largely depend on Japan's response: "Unless Japan responds to the growing power of China, China will dominate its region and become increasingly influential beyond it" (Waltz 1993, 68-69).

As indicated earlier, many recent works-not all explicitly realisthave tended to rehearse these ideas. James Hsiung, for example, claims that Japan has taken "countermeasures aimed at rearming" as a way of dealing with the alarm arguably caused by China's rise (Hsiung 2007, 1617). The vast literature on Japan's alleged "remilitarization" or "normalization" in the 2000s has also often treated China's rise as the primary independent variable to explain what is seen as increased Japanese internal balancing (Samuels 2006, 114; Pyle 2007, 2; Hughes and Krauss 2007, 168; Hughes 2009, 87). To quote just two typical examples of this view, David Arase writes that "the insecurity and rivalry caused by the rise of China is driving an expansion of military capabilities in Japan" (Arase 2007, 578), and Andrew Oros claims that China's growing military spending "is a primary driver of Japan's defense policies" (Oros 2007, 43).

As for external balancing, John Mearsheimer believes that Japan is "certain to fear" the rise of China and "will join an American-led balancing coalition to check China's rise" (Mearsheimer 2006, 162). Many others agree (Shinoda 2007, 172; Hughes and Krauss 2007, 168; Odgaard 2008, 193-194). Robert Ross, for instance, writes, "As China has risen, Japan has strengthened defense cooperation with the United States. It has become Washington's . . . most robust partner against the rise of China" (Ross 2005, 82; see also Ross 2006, 387-389).

Many observers have portrayed Japan as an outlier in East Asia-a rare exception to the observed regional tendency of accommodating China's rise (Shambaugh 2004-2005, 67; Kang 2007). Michael Heazle and Nick Knight, for example, claim that "[Japanese] security anxieties over China's current and future influence [are] . . out of step with a broader regional trend over the last decade towards perceiving China in terms of the economic opportunities and stability its modernization presents" (Heazle and Knight 2007, 9).

Analogous arguments are also widespread in the Chinese discourse (Sasaki 2010, 565). Xuetong Yan, for instance, views "deterioration" in the relationship as the result of a "much tougher [Japanese] foreign policy towards China," adopted in order to deal with the challenge China's rise poses to Japan's power status (Yan 2006, 15). Men Honghua observes a "strengthened [Japanese] containment of China in the fields of security and strategy" (Men 2008, 21), and Lin Zhibo writes, "The fundamental conflict between China and Japan now is that China is rising, 
and Japan does not want to see China rise. This conflict is long-term and cannot be altered by the will of the Chinese people" (Lin 2005).

A sizable body of literature thus maintains the notion that Tokyo is trying to contain China's rise to power-indeed, the assumption that it is bound to do so-and that tensions in the relationship can be explained accordingly. Dissenting voices are admittedly also represented in the discourse. David Kang, for instance, has emphasized that balancing should not be "the default hypothesis in international relations," especially when it comes to analyzing relations in Asia (Kang 2003-2004, 166; see also Chan 2010). Still, the balancing narrative remains very influential, and, arguably, its prevalence in the literature greatly affects our understanding of China's rise thus far, as well as its future trajectory. Since it takes China's rise to be a phenomenon that is occurring in isolation from Japan, and in a way that Tokyo can only react against, there is a risk that this narrative underestimates Japan's own role in facilitating the rise of China.

In contrast, we aim in this article to question and qualify this widespread understanding of the Japanese response to China's rise. This aim is operationalized by examining how Japan has handled China's rise between 1978 and 2011. More precisely, how has Japan dealt with China's long-term core strategic interests, which are embodied in the post-1978 Chinese "grand strategy" that is believed to have contributed to China's rise? Contrary to the opinion of most observers, we find that Tokyo has not pursued a policy of containment toward China, but neither has it simply followed a policy of engagement (e.g., Mochizuki 2007; Hughes 2009). We hope to demonstrate here that Japan has to a significant degree been conducive in accommodating China's rise. It has done so, most importantly, by facilitating the successful implementation of China's grand strategy, and hence by respecting China's core interests and acting accordingly.

By focusing on Japan's response to the rise of China we offer in this article a critical test of balancing theory. Realism has been declared obsolete by some (e.g., Lebow 1994; Legro and Moravcsik 1999). However, the academic standing of a research program cannot solely be judged by how it fares in theoretical debates. IR theory is after all a tool to make sense of international politics. A research program's popularity in writings on empirical issues must therefore be taken into account when judging its vitality. Especially, one should pay attention to what degree its core assumptions permeate the field. By this yardstick, the idea that states tend to balance, either against power or threat, is still a very 
dominant view among scholars writing on East Asian international relations. The view is far from limited to those who would describe themselves as realists. Balancing can be described as the default expected behavior in the academic debate on East Asian international politics.

Facing the rise of China, East Asia currently has all the characteristics of a situation where one ought to find balancing behavior. It should be an "easy case" for the theory. Putting it simply, if China's neighbors do not balance against the country, where else can realism expect to see balancing? Moreover, Japan is perhaps the country in East Asia with the clearest incentives to balance against China's rise. It has the material resources to balance internally; it could use its military alliance with the United States to balance externally; and, furthermore, it could exploit its leverage in the region to interfere with Chinese ambitions. In addition, Japan and China have a history of power struggles and interstate conflict, and they are still involved in an unresolved territorial dispute. Therefore, even if East Asia as a whole has not balanced against China, it would go some way to "save" balancing theory if Japan has done so.

Japan's response to China's rise is also a very useful prism through which broader Japanese China policy can be understood-as could indeed the overall Sino-Japanese relationship. At the same time, it is important to emphasize that our study is rather narrow in the sense that we consciously exclude all matters that are not part of Japan's response to China's grand strategy, including several of the most pressing issues in the relationship-for example, what is often referred to as the "history" or "memory" issue (e.g., He 2008; Gustafsson 2011). Still, Japan cannot in any meaningful way facilitate or counteract China's rise outside the framework under scrutiny here-that of China's grand strategy.

Our study is also narrow in the sense that it does not explore the intentions or interests behind Japan's accommodating China policy. Although many analysts tend to regard an explanation of Japan's China policy as essential to any account of the subject matter, arguments as to why Japan has approached China's rise in a certain way would not necessarily elucidate the problem under investigation here. Neither would an attempt to calibrate the most rational Japanese response to Chinese grand strategy. Instead, we propose a focused study of Japan's actual response to China's rise. The aim, again, is to illuminate the extent to which it fits the definitions of "containment" and "accommodation," and with what implications. Although we do not purport to test alternate explanations, a call for such an effort may well be part of the conclusion. One final omission, of course, is China's Japan policy. 
In the next section, we define the core concepts of the article, in particular "rising power" and "grand strategy," and present different possible international responses to rising powers.

\section{Rising Powers and Grand Strategy}

A rising power is defined here as a state in the process of agglomerating capability at a rate that exceeds that of other powers. In China's case, "rise" reflects the country's transformation from a regional middle-ranking power to a great power/superpower in the international system. Not only have Chinese capabilities grown in absolute terms in this period, but inherent in the understanding of China's rise is also the notion that it has occurred at least partly at the expense of other states' relative power (Yan 2006, 12-13).

History demonstrates that rising powers ascend in different ways (see Kennedy 1989), and Jeffrey Legro emphasizes the significance of "purpose transition" for understanding such differences: "While power is undeniably important in affecting transitions, power does not unilaterally determine purpose" (Legro 2008, 169). The implication is counterintuitive for balance-of-power realism (Layne 1993, 13-14), but not necessarily for balance-of-threat realism (Walt 1987, 25-26); capability alone is insufficient for hypothesizing about the trajectory of a rising power. For example, Japan's prewar rise was completely different from its rise in the postwar period; militarist Japan in the 1930s simply had a different purpose or grand strategy than the "pacifist" "trading state" in the 1960s through the 1980s, and the outside world's response differed accordingly. ${ }^{1}$

A grand strategy is defined here as a set of collectively held ideas about how a state should pursue its long-term strategic interests by employing, combining, and enhancing its capabilities - military and civilian ones alike (Kennedy 1991, 4; Posen 1984, 13). A grand strategy guides a state's relationship with the international system, but the term takes on a far wider meaning than simply "foreign/security policy agenda," because it is tightly knit to both foreign and domestic policies. Furthermore, a grand strategy lays out core national interests, and it is the result of trade-offs between actors representing different ideas of how to employ and enhance state power (Kennedy 1991, 2-7).

The process whereby a state decides to employ a new grand strategy usually involves a redefinition of its core interests, or at least a complete overhaul of the means through which to fulfill those interests. The set of policies that enabled China's rise could arguably be deduced from 
the post-Mao leadership's radical redefinition of national priorities from 1976 onward, and hence from the new Chinese grand strategy.

The idea that Japan balances against or contains the rise of China derives from an understanding that Tokyo views China's rise, and consequently China's grand strategy, as essentially threatening. Hence, China's grand strategy becomes an excellent context in which to evaluate Japan's response to the rise.

\section{Responses to Rising Powers}

How then is the international system expected to deal with rising powers? Randall Schweller outlines five basic responses in addition to "balancing": "preventive war," "bandwagoning," "binding," "engagement," and "distancing/buck-passing" (Schweller 1999, 7-18). Although theorists tend to ascribe different importance to these strategies, Japan's response to China's rise is in any case most commonly interpreted as one of balancing/containment. Schweller defines balancing as "opposing the stronger or more threatening side in a conflict" (Schweller 1999, 9; cf. Waltz 1979, 126-128; Paul 2004, 3), again either through the mobilization of national resources (internal balancing) or through the use of alliances (external balancing). Most of the arguments we review in this article emphasize that Japan has used a combination of the two.

"Containment" is closely related to balancing, but it differs in that it is "designed to maintain the balance, not to restore it" (Schweller 1999, 10). In short, containment is a strategy to prevent the rising power's "further expansion." Since balancing essentially means allying with the weaker side in a power struggle, it would make little sense to claim that Japan is balancing against China together with the United States. The reason, of course, is that the United States would have to be classified as the most powerful actor in the East Asian theater, and thus it would theoretically have to be the main object of other countries' balancing behavior (Shambaugh 2004-2005, 66; see also Chan 2010). Following Schweller's definition, the most coherent understanding of Japan's China policy would thus be that Japan has attempted to contain China's rise rather than balance against it.

As for the other ways of responding to rising powers, buck-passing essentially means free-riding on the balancing efforts of other states. Japanese postwar foreign policy restraint has sometimes been interpreted in terms of exactly such a strategy (Lind 2004), and it serves as the main alternative to balancing in offensive realism (Mearsheimer 2001). Bandwagoning, in contrast, is taken to be the very opposite of balancing, because it signifies coalition with the stronger side in a con- 
flict (Schweller 1999, 10; Waltz 1979, 126). The goal of bandwagoning is generally not to control a rising power, but rather to profit from its rise (Schweller 1994). A decade ago, Reinhard Drifte predicted bandwagoning to be one plausible scenario for Japan's future China policy, but he also stated that the more likely one-at least for the time beingwas increased balancing against China within the perimeters of the Japan-US alliance (Drifte 2003).

Finally, binding and engagement share the goal of controlling the rising power, but they diverge from balancing in terms of means. While binding marks a strategy of allying with a rival in order to control it, engagement signifies the use of noncoercive means, often rewards, "to ameliorate the non-status quo elements of a rising power's behavior" and to socialize it "into acceptance of the established order" (Schweller $1999,14)$. The main objective of an engagement policy is thus "to minimize conflict and avoid war without compromising the integrity of the existing international order" (Schweller 1999, 14).

To accommodate a state's rise means to help it become more powerful. For the purpose of this article, accommodation is understood as a possible outcome of Japan's behavior, and not as an intentional strategy. None of the terms "engagement," "binding," or "bandwagoning" captures this meaning. However, all these strategies can result in accommodation, and an accommodating outcome does not exclude any of them. For instance, state A can accommodate state B through an engagement policy. Then again, engagement does not necessarily lead to accommodation.

In this article, we evaluate Japan's response to China's rise between 1978 and 2011 by comparing Japanese actual policy with the line of action that Beijing would ideally prefer Western great powers to pursue. ${ }^{2}$ The method is fairly straightforward. First, a framework of China's post-1978 grand strategy is reconstructed-an endeavor that is arguably facilitated by its relative coherence, at least compared to the strategies of most other great powers (Kennedy 1989, 576). Nine indicators are then chosen to operationalize different aspects of the grand strategy. Second, Tokyo's response is classified depending on the level of correspondence with regard to Beijing's interests. A Japanese policy of consistent conformity is classified as "strong," and, conversely, a "weak" mark signifies a behavior that has run counter to Chinese interests. In cases where the results do not clearly confirm one of these ideal types, a "mixed" classification seems most suitable. In this context, "Tokyo" or "Japan" is not meant as a reified monolith or a unitary actor. The fact that the nine indicators span rather diverse policy areas guarantees that the views and actions of rather broad sectors of the Japanese policymaking apparatus are reflected in the analysis. 


\section{China's Grand Strategy:}

\section{The Restoration of China as a Great Power}

In the postwar period, Beijing's overriding foreign policy goal has been to alter the predicament China was forced to endure during the "century of humiliation," from the mid-nineteenth century on the eve of the Opium War until the establishment of the People's Republic of China in 1949. In other words, the regime has aspired to regain the power status enjoyed by the historically most powerful Chinese dynasties. In the parlance of international relations (IR) theory, this goal is equivalent to achieving great power status (Yan 2006, 13). Although this objective has remained stable since 1949 , the preferred means have changed greatly as a result of the post-Mao leadership shifting from a revisionist grand strategy to a more integrationist approach to the Western-led international order. Post-Mao leadership concluded that only the great capitalist powers in the Western camp could provide the capital, technological and managerial know-how, and leadership in international organizations that China needed to fulfill this goal. Deng Xiaoping's most important foreign policy choice was thus to rely on Western support to achieve development and modernization.

The post-1978 grand strategy has also not been static. It has been modified over time, notably from the mid-1990s onward, but these modifications were mere adjustments rather than evidence of a new grand strategy. Nor has the Western response to China been monolithic over the thirty-some years that have passed since Deng's strategic shift, but overall China's rise has proceeded without provoking any major conflicts. At the same time, this outcome was far from inevitable.

What did Beijing expect from the West in order to achieve this shift? First, it sought to secure the unity of the country - the supreme task for any Chinese government. Second, it requested help to achieve effective economic development-the prerequisite for China's rise. Third, it looked for acceptance of its steadily growing military spending, in line with the aspiration to consolidate China's position as a regional military power. The post-1978 grand strategy could thus be divided into three subgoals, each of which reflects different aspects of the strategy:3

1. Secure the unity of China under Communist Party rule.

2. Develop the economy through integration in the global economic system.

3. Rise "peacefully" as a regional power.

The subgoals overlap to a certain extent, but they are considered separately for the sake of analytical clarity. They are of equal and core im- 
portance to the Chinese grand strategy. Each subgoal is represented in the analysis by three indicators.

The subgoals and indicators are presented in Table 1 and in detail in the following sections. Here it suffices to repeat that Tokyo's response for each indicator is evaluated according to its level of correspondence with Beijing's interests. The subgoals and indicators thus structure the analysis.

\title{
Secure the Unity of China Under Communist Party Rule
}

This subgoal to a large extent overlaps with security interests as defined by balance-of-power theory, and it includes territorial integrity, national sovereignty, and regime legitimacy. To facilitate these objectives, Beijing has kept insisting that the outside world should not interfere in its domestic affairs. Moreover, it has often done so in the face of harsh Western criticism that the Chinese principle of noninterference conflicts with "universal human rights standards." To get the principle fully accepted by the Western powers thus carries symbolic meaning; as long as other states judge that they can afford to push Beijing on "non-negotiable issues," there is proof that its grand strategy has still not fully succeeded. Hence, how the established great powers have responded to this subgoal has been a sort of litmus test for Beijing (Chen 1996, 460-461).

Operationalizing this subgoal, Beijing has demanded (1) respect for China's stance in territorial conflicts, most importantly acceptance of the "one China" policy regarding the political status of Taiwan; (2) the isolation of so-called anti-China forces, notably the India-based Tibetan

\section{Table 1 Subgoals and Indicators of China's Grand Strategy}

\author{
Secure the unity of China under Communist Party rule \\ Territorial integrity \\ National sovereignty \\ Regime legitimacy \\ Develop the economy through integration in the global economic system \\ Trade \\ Foreign direct investment \\ Foreign aid \\ Rise "peacefully" as a regional power \\ Military modernization and buildup \\ Regional economic integration \\ Regional security cooperation
}


government in exile and its leader, Tenzin Gyatsu, the fourteenth Dalai Lama; and (3) support for the continued one-party rule of the Chinese Communist Party (CCP). The latter has manifested itself in demands for noninterference in the face of harsh measures that the CCP deems necessary to guarantee its monopoly of political power, such as the killing of protesters at Tiananmen Square in June 1989.

\section{Territorial Integrity}

During the reform period, China has not compromised in any of the territorial disputes over offshore islands in which it is involved, but, apart from a few episodes of military escalation, has generally chosen to delay these conflicts in order to avoid upsetting regional stability (Fravel 2008, 269-270). In addition to offshore islands disputes, Beijing has also grappled with "homeland disputes"- territorial issues seen as domestic affairs, namely over Hong Kong, Macau, and Taiwan (Fravel 2008,220 ). The most crucial of these issues is the ongoing dispute over Taiwan.

Taiwan has been a constant conundrum for the PRC since 1949, and Beijing's official policy is that the island is a renegade province that needs to be reunified with the mainland. How to settle Taiwan's ambiguous international status and incorporate it into China has been described as "the most important issue for China's foreign and security policy" (Tsang 2008, 52). The PRC has made a number of demands on the outside world, all serving to facilitate cross-strait moves toward reunification and to discourage Taiwanese moves toward independence.

To sum up, Beijing has preferred other governments to (1) comply with its delaying strategy in offshore islands disputes; (2) accept the "one China" policy; (3) have no diplomatic relations with Taiwan; (4) refrain from granting visas to incumbent Taiwanese political leaders; (5) prevent Taiwan from joining international organizations where statehood is a requirement of membership; and (6) abstain from selling weapons to Taiwan.

Japan's Taiwan policy carries particular significance for Beijing; not only is Japan geographically close to Taiwan, but it also colonized the island between 1895 and 1945, and it maintains an alliance with Taiwan's security guarantor, the United States. Tokyo has clearly complied with China's basic framework for handling the Taiwan issue (Noble 2005), which goes some way toward meeting Beijing's interests. In the Joint Communiqué that was signed when Sino-Japanese relations were normalized in 1972, Tokyo recognized the PRC government as the sole legal government of China and declared that it "understood" and "re- 
spected" the view that Taiwan is an inalienable part of the PRC territory (Joint Communiqué of the Government of Japan and the Government of the People's Republic of China September 29, 1972). Moreover, in the 1978 Sino-Japanese Treaty of Peace and Friendship, Japan pledged to respect the principle of "sovereignty and territorial integrity" as well as "non-interference in each other's internal affairs" (Ministry of Foreign Affairs of Japan 1978).

Tokyo has reiterated these points on numerous occasions. As a consequence, it has no official relations with Taiwan; it has refrained from selling weapons to Taiwan; and it has not concluded an equivalent of the United States' Taiwan Relations Act. Incumbent Taiwanese leaders have furthermore been denied a visa to visit Japan (Deng 2008, 254). Moreover, when Taiwanese president Chen Shui-bian planned a "defensive referendum" on Taiwanese independence in 2004, Tokyo expressed concern over the development and reassured Beijing that it would continue to abide by the Joint Communiqué (Hu 2006, 97; Noble 2005, 3-4).

From Beijing's perspective, however, some parts of Japan's Taiwan policy remain unsatisfactory. First, two joint declarations between Japan and the United States in 1996 and 2005 have conflicted with Beijing's view of cross-strait affairs as a solely internal affair (Gill 2007, 145-146). In particular, the 2005 declaration expressed hope for a peaceful resolution in the Taiwan Strait and demanded that China enhance the transparency of its military affairs. It could even be interpreted as the Japan-US military alliance aiming to encompass the security of Taiwan (Xinhuanet 2005). Second, in 2007-2008, Japan was not as unequivocal as the United States in opposing Taiwanese attempts to stage a popular referendum about whether to apply for UN membership in its own right (Hagström 2008-2009, 233).

The offshore island dispute in which Japan's behavior has carried most relevance to Beijing is without doubt the one over the Japancontrolled Senkaku/Diaoyu Islands. Beijing has mostly adhered to the default policy of delaying or shelving the dispute, as first declared by Deng in 1978. While strictly emphasizing the legitimacy of its claim, Tokyo has generally respected Beijing's interests by employing measures to prevent the disagreement from escalating (Hagström 2005b, 170). For example, Japanese citizens have been prevented from visiting the islands (Fravel 2008, 317), and Diet members making visits therefor example, Nishimura Shingo of the New Frontier Party on May 6, 1997-have been officially criticized (Hagström 2005b, 178). Furthermore, no land surveyors are being dispatched to the islands, a heliport is not being maintained, and no hunters are sent to kill the more than 1,000 
goats that are rapidly destroying the unique island flora. ${ }^{4}$ At the same time, in September 2010, Japan took unprecedented measures against a Chinese fishing vessel that had entered the territorial waters of the islands and collided with a Japanese patrol boat. The captain was arrested and detained, and his detention was even extended before he was eventually released. Many analysts would remark that the captain was released "under strong Chinese pressure," referring to the subsequent arrest of Japanese Fujita employees in China and the suspension of rare earth metal exports to Japan for two months, but the alleged causal connection between these occurrences is dubious (Hagström, forthcoming 2012).

In sum, Tokyo's record in dealing with China's territorial integrity must be classified as mixed. Although Tokyo has vehemently criticized the Chinese idea that the territorial affiliation of the Senkaku/Diaoyu Islands is disputed, it has maintained a careful and cautious attitude visà-vis the dispute - at least until the fall of 2010. Moreover, Tokyo has generally complied with China's basic framework for Taiwan, although its Taiwan policy could probably have been more forthcoming from Beijing's perspective.

\section{National Sovereignty}

China is a multiethnic state harboring numerous ethnic minorities. How to suppress attempts to achieve independence or greater autonomy for regions predominantly inhabited by such minorities is a dilemma that the PRC has inherited from its imperial predecessors.

The way in which foreign countries deal with the Tibetan spiritual leader and head of the "Tibetan government in exile," the Dalai Lama, is analyzed here as an indicator of their approach to China's national sovereignty. 5 The Tibetans are not the only ethnic minority within the PRC seeking greater autonomy, but they are arguably the most vocal one. The Tibetan uprising in 1959, for example, is still the most serious domestic threat to PRC sovereignty thus far (Fravel 2008, 71-97). In China's international relations, the Dalai Lama has assumed a symbolic meaning unmatched by any other minority issue.

Since the Chinese government considers the Dalai Lama's meetings with foreign leaders as part of his "separatist activities," it views meeting the Tibetan leader as tantamount to interference with Chinese sovereignty and potentially as an act of hostility. Beijing has frequently reiterated the stance that a high-level meeting with the Dalai Lama can have serious repercussions for any country's relations with China (for several examples, see Fuchs and Klann 2010). 
The Tibetan Nobel Peace Prize winner has a large following around the world, and meeting him is hardly viewed as controversial except by the PRC. To refrain from meeting the Dalai Lama could thus be understood as tacit acknowledgment of the PRC's concept of noninterference. In this regard, it makes an excellent indicator of how well other states have respected China's national sovereignty.

Between 1978 and 2011, the Dalai Lama was granted a visa on fifteen occasions to visit Japan. He has received invitations from Buddhist and Shinto organizations alike, but the host organization has never been one of Japan's big, traditional Buddhist schools (Repp 2008, 123). The Japanese government has upheld a strict policy of not meeting the Tibetan religious leader, and it has taken steps to ensure that his visits do not take on a symbolic political meaning that could harm the relationship with Beijing. ${ }^{6}$ For example, in 2000, the government interfered with a planned meeting between the Dalai Lama and Tokyo governor Ishihara Shintaro by informing the Tibetan leader that Japan would never again grant him a reentry visa if he met with Ishihara, who was and remains a staunch critic of China (Kyodo 2000).

However, in November 2011, Prime Minister Noda Yoshihiko's special adviser on foreign and security matters, Nagashima Akihisa, and the senior vice-minister for defense, Watanabe Shu, deviated from the official policy and met the Dalai Lama. Afterward, as chief cabinet secretary Fujimura Osamu gave them an official reprimand, Nagashima defended himself by claiming that he had attended the meeting in his capacity as an individual lawmaker (Fujimura 2011).

The Tibetan government in exile has repeatedly criticized Japan's official approach. For example, in 1998, the representative of the Liaison Office in Tokyo, Karma Gelek Yuthok, stated: "The Dalai Lama meets presidents, prime ministers and ministers when he travels. But he can't meet with them in Japan, and this shows a certain weakness. We are anxiously awaiting change" (quoted in Repp 2008, 122). In 2009, Kelsang Gyaltsen, the Dalai Lama's representative in Europe, also criticized the Japanese government and requested Japan to change in order to "reflect the public sentiment of the Japanese population" (Hongo 2009). Still, Tokyo has not given in to internal and external pressures; instead, it has kept insisting on a policy of depoliticizing the Tibetan issue. Moreover, unlike Washington and several Western European governments, Tokyo has chosen not to play the "Dalai Card" in its relations with Beijing (Hagström and Jerdén 2010, 730-732). Hence, Tokyo's correspondence with Beijing's interests clearly has to be classified as strong during the period under study. 


\section{Regime Legitimacy}

The CCP sees the sustained stifling of dissent as necessary for ensuring its continued monopoly on political power. Its methods are often appalling by human rights standards officially espoused by Western governments. The event that most starkly presented China's democratic partners with the hard choice between castigating the grim outcomes of one-party rule and respecting China's regime legitimacy was the violent crackdown on peaceful prodemocracy protestors at Beijing's Tiananmen Square and other places in China in early June 1989. The repression was not a deviation from the grand strategy, nor did antireform forces perpetrate it. On the contrary, Deng allegedly feared that toorapid societal changes would bring about chaos and disorder, thus jeopardizing the country's stability, which he regarded as a prerequisite for modernization (Deng 1994b, 279-280).

Until 1989, engagement with China had been justified by Western leaders on the assumption that the communist dictatorship's shift toward a more market-oriented economy would expose it to outside influences and facilitate a transition to a more liberal and democratic society. However, after Tiananmen it became obvious that such a development was by no means preordained, and the PRC became the target of harsh criticism, eventually leading to diplomatic and economic sanctions. As a result, foreign investment in China declined sharply, and so did trade with the country (Zhang 1998, 57). More importantly, however, the precious momentum that had been built up during the preceding decade risked being forfeited. To continue the modernization process, it was imperative for Beijing to restore its foreign relations speedily while at the same time projecting an appearance of not yielding to outside criticism. To succeed, Beijing needed support from within the Western camp.

To sum up, Beijing has generally preferred other governments to abstain from bringing pressure to bear over human rights issues. After the military crackdown in early June 1989, it specifically preferred other countries to (1) refrain from harsh criticism and from advocating or implementing diplomatic and economic sanctions and (2) work to ameliorate the international community's relations with China.

Tokyo has adhered to the overall framework rather well. The USbased nongovernmental organization Human Rights Watch claims that Japan has been "extremely hesitant in publicly raising human rights issues" with China (Doi 2010). This policy allegedly reflects Tokyo's general disinclination to decisively promote a human rights agenda in Asia (cf. Arase 1993, 949). 
The Tiananmen issue was handled quite in line with the general Japanese policy of not politicizing human rights and democracy in the relationship with China. Tokyo's reaction to the crackdown was very restrained compared to that of other countries within the Western camp. It temporarily suspended a yen loan to China (see the second subgoal in the next section), but it emphasized that the freeze was merely a "response" and not a "sanction" (Katada 2001, 44). Tokyo also lobbied for a restrained response within the Western camp. The absence of joint sanctions and the relatively conciliatory tone at the G7 summit in Paris in July 1989 reflected the approach championed by Prime Minister Uno Sosuke (Zhang 1998, 66; Kesavan 1990, 674). The fact that Japan's proengagement stance was approved by the administration of George H. W. Bush might even suggest that Japan's policy strengthened moderate forces in the United States and thus helped alleviate tensions at this very critical juncture of China's ascent (Mochizuki 2007).

Later in 1989, the Japan-China Investment Promotion Organization was set up to facilitate Japanese investments in China; in July the following year, the Japanese government officially decided to unfreeze the third yen loan to China; and in August 1991, Prime Minister Kaifu Toshiki visited Beijing, as the first Western head of government to do so after Tiananmen (Deng 1997, 381).

Arase argues that Tokyo after Tiananmen "not only ... acted consistently to shield China from Western pressure, but in subtle ways has aided the repressive policies of the regime in Beijing" (Arase 1993, 945). From Beijing's perspective, Japan's efforts thus helped sustain the gaige kaifang (reform and opening up) policies (Zhang 1998, 66). In September 1989, Deng approvingly remarked that the Japanese attitude toward China "was especially different from that of the United States" (Tanaka 1991, 180; see also Deng 1994b, 335).

In sum, Tokyo has consistently stuck to low-key human rights diplomacy toward China, and hence its correspondence with Beijing's interests must be classified as strong. Its handling of the Tiananmen incident is an illustrative case in point.

\section{Develop the Economy Through Integration in the Global Economic System}

China's foreign economic relations had been very modest up to the point when Deng decided that the country should radically alter its development strategy and start to take advantage of the Westerndominated international economic system in its quest for development 
(Hart 2008, 31, 33; Ross 1994, 444). Using Legro's terminology, the "shock" of the Cultural Revolution (1966-1976) and the death of Mao (1976) led to the "collapse" of the thinking behind the earlier mode of modernization, and a "replacement idea" (i.e., gaige kaifang) eventually started to take root (Legro 2005, chaps. 1-2).

In this section, we look more closely at some international factors deemed crucial to the aim of achieving effective economic development. The PRC has needed access to foreign markets as well as incorporation into the institutional web of regimes that governs international economic activity, notably the World Trade Organization (WTO). It has also had to attract FDI and foreign aid in order to develop its infrastructure and industrial base.

\section{Trade}

In the late 1970s, the PRC made a major break with prior policies and decided to expand exports in order to gain foreign capital. Initially, trade liberalization in the late 1970s and early 1980s failed to bring about significantly increased trade volumes. In the 1990s, however, foreign trade expanded sharply, and it continued to do so in the 2000s as China succeeded in mirroring the export-led growth strategy pioneered by Japan and the East Asian "tiger economies" in earlier decades (Goldstein 2005, 53-54; Ross 1994, 444-448; Pearson 2001, 357).

In 1986, Beijing started its campaign to gain full membership in the General Agreement on Tariffs and Trade (GATT), and it continued its efforts vis-à-vis the WTO from its founding in 1995 (Pearson 2001, 337-341). The deal between China and the United States was finally settled in 1999, and China joined the WTO in 2001. China's entry was symbolically significant; most importantly, it signified "China's coming of age as a participant in the global economic community" (Naughton 2007, 377). China's trade has grown exponentially since then; between 2000 and 2008, exports increased by 574 percent and imports by 503 percent, to retract somewhat in 2009 in the wake of the global financial crisis (International Monetary Fund 2007, 2010).

To sum up thus far, Beijing has generally wanted other governments to promote bilateral trade with China, and before 2001 it wanted them to support Chinese membership in the GATT/WTO.

Japan has been more than willing to accommodate these interests and has shown no interest in using sanctions or in any other way restraining its trade with China. Sino-Japanese trade already had a comparatively solid basis at the time of Deng's introduction of gaige kaifang, and Japan has since maintained its position as one of China's 
foremost trading partners. Japan's share of China's total trade during the period 1978-2009 amounted to 13.8 percent (11.5 percent of imports and 16.4 percent of exports) (International Monetary Fund 1985, 1992, 1998, 2003, 2007, 2010), and its importance as a market for Chinese products has allegedly contributed to China's export-aided growth strategy. Japanese politicians have moreover been very supportive in increasing bilateral trade through different measures (Hilpert and Nakagane 2002, 139-140).

Japan was also a strong supporter of China's joining the WTO. The two countries signed an agreement on China's membership bid when Prime Minister Obuchi Keizo visited Beijing in July 1999 (Tanaka 2007, 261) - that is, well in advance of China's settlements with the United States and the European Union.

In sum, Japan is one of China's top trading partners-a development that Japanese economic policy has helped bring about-and has strongly supported Chinese membership in the WTO. There is thus solid evidence that Tokyo's stance has corresponded strongly with Beijing's interests throughout the period.

\section{Foreign Direct Investment}

During the Mao era, foreign investment was commonly viewed as a tool for exposing China to undue foreign influence. However, following the introduction of gaige kaifang in 1979, China began accepting FDI (Ross 1994, 444-445). The same year, a joint venture law was introduced, and in 1980, four special economic zones were established in coastal southern China (Zhang 1998, 54).

The goal behind the decision to open up to FDI was twofold: (1) to increase foreign currency earnings from the establishment of exportoriented industries, and (2) to introduce much-needed advanced technology into the country. However, the volume of FDI only started to increase in the mid-1980s as the country enacted domestically controversial reforms that gave foreign investors a more direct role in the economy (Ross 1994, 448-449; Zhang 1998, 53-57).

The aftermath of Tiananmen saw a slump in inward investment into China, but FDI took off again in the wake of Deng's famous "Southern Tour" in 1992, when he visited early modernized cities in southern China and encouraged further reform (Deng 1994b, 360). One can thus conclude that, overall, Beijing has wanted other governments to promote FDI in China.

In a meeting with Japanese prime minister Nakasone Yasuhiro in 1984, Deng characterized Japanese FDI in China as being "very bleak," 
and he asked Nakasone to encourage an increase (Deng 1994b, 63). But it was not until the value of the yen started to appreciate after the Plaza Agreement in 1985 that Japanese interest in China as a destination for FDI really started to surge (Hagström 2005a, 92-93).

After eight years of on-and-off negotiations, the two countries signed the Japan-China Bilateral Investment Treaty in 1989. Tokyo persuaded Beijing to accept conditions that it had thus far been very reluctant to comply with, above all "national treatment," but in return the Japanese government subsequently increased its measures to promote FDI (Hagström 2005a, chap. 3).

FDI volumes grew steadily until 1995 . After 1995 , however, they waned again until 2000. The big surge in Japanese FDI in China took off during the first half of the 2000s (Naughton 2007, 414; OECD $2010 b$ ), curiously coinciding with the "political ice age" of the Koizumi era. In absolute figures, Japanese FDI in China has been more substantial than that of almost all other countries (OECD 2010b). Moreover, much Japanese investment is not included in these figures, because it has been channeled from Hong Kong and Taiwan through partnerships (Zhang 1998, 53).

In sum, Tokyo's official policy has helped make Japan one of the main foreign investors in China since 1978. One thus has to conclude that its correspondence with Beijing's interests has remained strong throughout the period under study.

\section{Foreign Aid}

China opened up to foreign aid in 1978. Just as with trade liberalization and the acceptance of FDI, the decision to accept aid was a result of the gaige kaifang paradigm shift, and it spearheaded those other policies (Ross 1994, 444). The total amount of aid received during the reform period has been relatively small compared to China's gross domestic product (GDP), and as the Chinese economy has grown, the need for aid has also diminished. Still, foreign aid was a much-needed source of capital during the initial efforts at economic modernization (Jin 2007, 319). Beijing has thus wanted other governments to grant it foreign aid-with few strings attached-and concentrated on bigger infrastructure projects.

Japan's initial decision to grant China “yen loans" followed Deng's visit to Japan in 1978, where he was to sign the Japan-China Peace and Friendship Treaty, and the first aid package to China lasted from April 1980 to 1984 . The beneficial conditions of the yen loans qualified them as official development assistance (ODA) according to the standards set 
by the Organization for Economic Cooperation and Development (OECD) (Jin 2008).

Since Beijing renounced war reparations when bilateral relations were normalized in 1972, it considered ODA as an obligation that Japan could not fail to meet (Katada 2001). Over the next three decades, ODA played a major role in Japan's economic and diplomatic dealings with China, but Tokyo was always careful not to make explicit linkages between aid and other political issues. ODA was nevertheless frozen postTiananmen in 1989 but resumed again in July the following year (Katada 2001, 45; Hagström 2005a, 95).

Japan has been by far the biggest donor to China during the reform period. Its total ODA to China between 1979 and 2009 made up just over 40 percent of China's aggregate net ODA receipts during the period (OECD 2010a). Jin summarizes the significance of ODA for China's economic development: “As China's economy took off during the first 20 years of the reform and opening up policy-at a time when China both absolutely and relatively was lacking capital and technology - the yen loans came to play the role of "charcoal sent in snowy weather' [xue zhong song tan]" (Jin 2008, 24). Frank Tipton and Huilin Xiao, moreover, argue that "although the aggregate impact of Japan's ODA in China has been very small, it is qualitatively greater than a simple comparison with total investment would indicate" (Tipton and Xiao 2006, 139). In particular, the yen loans contributed greatly to the development of China's basic infrastructure (Deng 1997, 378).

The Japanese government declared in 2005 that it would phase out ODA to China starting in 2008. The decision was made against the background of several developments, including China's successful economic development and the strained political relationship between the two countries. Although the decision was arguably taken for political reasons, Tokyo was careful not to present the termination as punishment for bad behavior. And Beijing accepted Japan's decision insofar as the phase-out was implemented without causing any obvious frictions in the relationship (Drifte 2006).

In sum, since Japan was the biggest and most important aid donor to China during the initial three decades of the reform and opening-up era, its correspondence with Beijing's interests must be deemed strong.

\section{Rise "Peacefully" as a Regional Power}

During the initial three decades of its existence, the PRC relied on a strategy of deterrence. It fought wars with South Korea, the United 
States, India, the Soviet Union, and Vietnam and resorted to a relatively high degree of violence in all these conflicts (Johnston 2004; Deng 2006, 186). It moreover built a legacy of interfering in Southeast Asian states' internal affairs by supporting armed insurgencies (Shambaugh 2004-2005, 77).

If China's neighbors continued to regard it as a potential threat, there could be negative implications for its rise. To alleviate regional fears, Deng emphasized a policy of not seeking international leadership or regional hegemony (Deng 1994b, 350). Moreover, in the late 1990s, Beijing started to engage proactively in confidence-building measures to counter what it views as "China threat" arguments (Deng 2006). An adviser to the leadership, Zheng Bijian, coined the phrase "peaceful rise" to promote an image of China as a responsible great power with no intention of violently upsetting the international order (Zheng 2005). In official parlance, the preferred phrase later changed to "peaceful development" and eventually to "harmonious world," in order to convey an even less threatening image. Still, "peaceful rise" should not be conceived as a pacifist strategy, because it does not exclude the use of force to defend China's core interests (Hu 2005).

Operationalizing this subgoal, China has sought acceptance of its steadily growing military spending in line with the aspiration to consolidate its position as a regional military power. Second, it has requested active support for its bids for membership in regional trade and securityfocused organizations because association with them could alleviate foreign anxiety about its growing military potential.

\section{Military Modernization and Buildup}

Even before the death of Mao, Deng had fiercely criticized the state of the Chinese army and lamented its factionalism, lack of discipline, inefficiency, and failure to implement party policies (Deng 1994a, 1315). While in power, he began an overhaul of the Chinese military, which involved downsizing in personnel, technical modernization, and capacity buildup (Fisher 2008, chaps. 3-4). The driving force behind these changes was an aspiration to develop military capabilities "commensurate with its status as a major power" (Shambaugh 2004-2005, 85; see also Deng 2008, 8-9).

There is much uncertainty about the exact figures for China's military spending, but it is clear that it has thrived in the period under examination (Fisher 2008, 16-17). An arms race between China and other great powers would intensify the image of China as a revisionist state, and, as reflected in Beijing's insistence on the peaceful nature of its rise, 
it has wished to avoid such a scenario (Deng 2006, 187). China has thus wanted other great powers to accept the notion of a peaceful Chinese trajectory, or at least to abstain from framing its military modernization and increasing military expenditure as a threat, and to refrain from rearmament in response to China's soaring defense spending.

Japanese policymakers manifest much insecurity about what they see as China's unpredictable behavior and unclear intentions. Still, Tokyo's basic stance has been to refrain from criticism of China's military modernization per se and rather just demand greater transparency and point out the need for "further attention" (Hagström 2008-2009; Hagström and Turesson 2009; Hagström and Jerdén 2010). There is also a lack of compelling evidence that other recent changes in Japanese security policy amount to a military containment of China. If Japan were balancing against China, one would have to expect its defense burden to be on the rise, but while China has increased its military spending by double-digit figures annually, Japan has kept its defense spending on a fixed level just below 1 percent of GDP.

Even though new goals and problems have been articulated in Japanese security policy over the past twenty years, and more advanced policy instruments have been obtained to fulfill goals both old and new, evidence is lacking overall that these changes would constitute a shift toward "re-militarization" (Hagström and Williamsson, 264-266; see also Oros 2008, chap. 7). Japan's security identity allegedly also remains one of "domestic anti-militarism," which places clear limits on "the re-emergence of militarist elements at home" (Oros 2008, 6).

Some observers argue that Tokyo tries to contain China militarily in cooperation with Washington. It is true that the Japan-US alliance was consolidated in the mid-1990s—-for example, through the April 1996 Japan-US Joint Declaration on Security (later enacted by the Diet as the revised Japan-US Defense Guidelines legislation in January 1999). Legislation in the aftermath of September 11, 2001, such as the AntiTerrorism Special Measures Law and the Iraq Reconstruction Special Measures Law, also facilitated Japanese participation in US-led military operations outside the scope of UN peacekeeping operations for the first time since World War II. Yet, the Japan-US security alliance does not itself contradict the Chinese grand strategy; to drastically reduce the US military presence in East Asia has simply not been a strategic objective for the PRC in the last three decades (Shambaugh 2004-2005, 91).

Moreover, Japan's tilt toward the United States is far from clearcut. From the viewpoint of balance-of-power theory, realists would have to expect Japan to use the alliance much more enthusiastically to 
contain China. Although the alliance stood strong throughout Koizumi's incumbency, and until the Liberal Democratic Party lost power in 2009, many analysts argue that it was significantly weakened by the new Democratic Party of Japan government's vacillating on the issue of relocating the US Futenma base in 2009-2010. Both the Hatoyama government's initial attempt to strike a more equal balance between the United States and China in 2009 and the long-standing disagreement between Japan and the United States over the latter's military presence in Okinawa contradict the claim that Tokyo is using the alliance to balance externally toward China.

The latest National Defense Program Guidelines (NDPG), approved by the Japanese cabinet in December 2010, describes China's military development in slightly stronger terms than previous Japanese policy documents. China's trend of military modernization, its development of a capacity for long-distance power projection, and its expanding activities in surrounding waters were characterized there as a "concern of the international community and the region" (Japan National Defense Program Guidelines, December 17, 2010). The revised NDPG will moreover be accompanied by a historic overhaul of Japan's military strategy and capability, with military weight shifting from Hokkaido to the Nansei Islands and with further upgrades in the country's naval and coastguard capabilities (Japan National Defense Program Guidelines, December 17, 2010).

Altogether, Japan has taken some steps that could be seen as reacting against China's military modernization. But, more importantly, it has not taken any significant steps in the direction of becoming a more conventional military power, and proof of both internal and external balancing is overall lacking, at least if one adheres to commonly accepted theoretical definitions. Hence, on balance, its correspondence with Beijing's interests has been mixed in this area.

\section{Regional Economic Cooperation}

Beijing has viewed membership in regional organizations as a way of alleviating regional anxieties about its growing power, and it has thus sought active support in its attempt to embed itself in the region's growing multilateral architecture. ${ }^{7}$ The course whereby China became an active proponent of regional integration can be seen as a learning process, in which the Chinese elite became increasingly aware of the advantages of regional integration and were reassured that it would not necessarily infringe upon its national interests (Shambaugh 2004-2005, 68-70; Wu 2009, 59). 
China's entry into the Asia-Pacific Economic Cooperation (APEC) in 1991 marked the start of its participation in regional multilateral mechanisms. Even though APEC has spurred further Asian integration, the forum itself lost popularity in China and other East Asian countries in the 2000s. Beijing has instead viewed ASEAN+3 (APT, consisting of the Association of Southeast Asian Nations plus China, Japan, and South Korea) as the natural building block of an East Asian community. Unlike APEC and the East Asia Summit (EAS), APT excludes countries that Beijing is reluctant to see as part of the inner circle of East Asian regionalism, notably the United States, India, and Australia (Wu 2009, $59-61)$.

In sum, Beijing has generally wanted other countries to support its efforts to join regional organizations and, moreover, to support China's preferred makeup and design of these organizations.

Although Tokyo and Beijing have at times advocated somewhat different ideas of what countries should be included in regional cooperation schemes, Japan has participated in most mechanisms embraced by the Chinese government, and it has supported or even proposed Chinese membership in important regional organizations. For instance, it backed China's membership bid to join APEC from its creation in 1989 (Deng 1997, 383), and it "quietly supported Chinese participation in the G-7 summits in the early 1990s and formally proposed China's participation in the Naha summit in Okinawa in July 2000" (Hu 2006, 97). Japan has also joined APT, the format favored by China (Fukushima 2009, 108). Its correspondence with China's interests has thus to be deemed strong.

\section{Regional Security Cooperation}

During the second half of the 1990s, China shifted from a critical to a more supportive view of more institutionalized regional security cooperation. In 1994, it joined the security dialogue ASEAN Regional Forum (ARF), and in 2001 it cofounded the Shanghai Cooperation Council (SCC). In addition, Beijing started to engage actively in official military exchanges and bilateral security dialogues (Gill 2007, chap. 2; Shambaugh 2004-2005, 68-70; Wu 2009, 56-57). While the focus of the SCC has been to facilitate security cooperation with Russia and Central Asian states, the Six-Party Talks (SPT) on the North Korean nuclear issue are the prime example of security-related regional integration and conflict alleviation in Northeast Asia (Wu 2009, 62).

Besides the Taiwan Strait, the Korean peninsula is currently the most acute security issue in China's immediate surroundings, and it is a matter in which Beijing's interests intersect with those of the United 
States, Russia, South Korea, and Japan. To maintain a beneficial regional environment favorable to its economic modernization, it is critically important for China to stabilize the current situation on the peninsula (Zhao 2006, 99). Beijing has chaired the SPT since their inauguration in 2003. This has harmonized with the new Chinese security agenda, and it has given Beijing an opportunity to play the role of a responsible regional great power (Zhao 2006, 99-100). In sum, Beijing has generally wanted other countries to support its chairmanship in the Six-Party Talks on the North Korean nuclear issue and its objectives within the talks.

Tokyo's interests with regard to the North Korean nuclear issue have largely converged with those of Beijing and the other governments involved in the SPT. They all dread military confrontation on the Korean peninsula and thus want to prevent further nuclear proliferation in the region (Zhao 2006, 102-103). Yoichiro Sato describes the SPT as an opportunity for the Sino-Japanese relationship: "North Korea's nuclear weapons development has provided an opportunity for the two countries to work together on a security matter within a multilateral framework" (Sato 2009, 115; see also Wu 2009, 63).

Still, Tokyo's concerns have in some respects differed from those of Beijing. Most importantly, Tokyo has seen regime change in Pyongyang as a long-term goal (Zhao 2006, 103-104). Moreover, because of its preoccupation with the so-called abduction issue - the North Korean abduction of at least seventeen Japanese citizens in the 1970s and 1980s-Tokyo has not played a very constructive role in the talks. ${ }^{8}$ It has consistently conditioned its provision of economic incentives, widely deemed crucial for a comprehensive and lasting solution of the nuclear conundrum, on the establishment of diplomatic relations with North Korea-a development that in turn hinges on a resolution of the abduction issue. From time to time, Tokyo's stance has in fact been even more uncompromising than that of its US ally (Hagström 2009).

Tokyo's correspondence with Beijing's interests has thus been mixed. It has supported China's chairmanship in the Six-Party Talks and largely subscribed to Beijing's objectives, but from Beijing's perspective, Japan has been too preoccupied with the abduction issue, and this has not facilitated the PRC's role as chair.

\section{Conclusion}

Our analysis has demonstrated that on the whole there is a consistent pattern of Tokyo respecting China's core interests and acting accordingly 
throughout the period under study (for a summary, see Table 2). Perfect correspondence would have suggested a Japanese bandwagoning policy, but that has not been the case here. Japan's policy has generally been compliant, but in some areas its response has been more "mixed." Furthermore, since Japanese correspondence has facilitated the successful implementation of China's grand strategy, and since China's grand strategy has in turn been successful in bringing about the remarkable rise of the country, it follows that Tokyo has accommodated the rise of China. Contrary to most of the literature in the field, we conclude that Japan has not been pursuing a policy of balancing or containment vis-à-vis China.

A realist would perhaps rebut that all that matters is how Tokyo handles the "high politics" of security and that the "mixed" results in response to China's military development, the Taiwan Strait, and the Korean peninsula are sufficient evidence of Japanese containment. In fact, the "mixed" classification with regard to these matters means that Japanese policy has not amounted to containment. It is true that Tokyo's correspondence in those areas has not been ideal from a Chinese perspective, but Tokyo's policy could have corresponded even less. Thus, the results suggest that evidence of Japanese containment is generally lacking.

Furthermore, high politics is not all that matters even to most realists. Given the security externalities of trade, a central tenet of neoreal-

Table 2 Japan's Level of Conformity with the Chinese Grand Strategy

\begin{tabular}{ll}
\hline Indicators of China's Grand Strategy & Japan's Level of Conformity \\
\hline Secure the unity of China under Communist & \\
Party rule & \\
Territorial integrity & Mixed \\
National sovereignty & Strong \\
Regime legitimacy & Strong \\
Develop the economy through integration in & \\
the global economic system & \\
Trade & \\
Foreign direct investment & Strong \\
Foreign aid & Strong \\
Rise "peacefully" as a regional power & Strong \\
Military modernization and buildup & \\
Regional economic integration & Mixed \\
Regional security cooperation & Strong \\
\hline
\end{tabular}


ist theory is that "the fundamental goal of states in any relationship is to prevent others from achieving advances in their relative capabilities" (Grieco 1988, 498). Hence, the assumption is that states care about relative gains more than absolute ones (Mearsheimer 1994-1995, 19-20). As Waltz writes, "Even the prospect of large absolute gains for both parties does not elicit their cooperation so long as each fears how the other will use its increased capabilities" (Waltz 1979, 105). Furthermore, since states are assumed to be bound to translate economic capability into military might (Waltz 1993, 64-69), to argue that Japan has contained China's rise while facilitating China's growing economic capabilities contradicts a core tenet of realism. Still further, state cohesion and continuing CCP rule have been prerequisites for China's rise-at least in the eyes of the Chinese leadership - and if one argues that Japan has contained China's rise, there is also a need to explain the overall lack of pressure on Beijing by Tokyo over human rights issues.

An influential view holds that Japan's China policy is characterized by "hedging," which is defined as a strategy that gives equal weight to economic and military security. According to this view, Japan "hedges" with the United States against security threats and "hedges" with other countries against economic dangers (Heginbotham and Samuels 2002). Hedging signifies a reluctance to choose a straightforward strategy on either extreme of the balancing-bandwagoning continuum (Goh 2006; Kang 2007). The observation that Tokyo does not put all its eggs in one basket is no doubt helpful to our understanding of Japan's overall foreign security policy. Still, it does not say very much about Japan's response to China's rise, apart from ruling out extreme bandwagoning and extreme containment. Indeed, the concept's analytical value seems quite limited-in short, what state with options does not hedge?

Moreover, the tendency to interpret Japan's policy as hedging offers yet another illustration of how realism's core assumptions permeate much of the writing on Japan's foreign security policy. In fact, many allegedly puzzling issues in East Asian IR in general—such as Japan's failure to remilitarize or the general lack of regional balancing toward China-are surprising only if one observes the world from a realist standpoint. Hedging, too, follows the logic of balancing theory. States are believed to hedge against a perceived power/threat, and the hedging intensifies - or, in some cases, even turns into balancing - relative to the corresponding power/threat. In this sense, the concept can be seen as an attempt to "save" realism and as a way for analysts to "hedge" their bets.

In contrast, our study offers a more precise assessment of Japan's response to China's rise by examining it both over time and across dif- 
ferent issue areas. The results show that Japan's behavior to a great extent has followed China's interests and has thus helped China become more powerful. This observation should be of interest to anyone who cares about how states' actions work to increase or decrease each other's relative capabilities.

The trend and direction of Japan's policies over time also contradict the expectation of balancing. Those who claim that Japan pursues a balancing policy typically trace its beginning to some time during the last fifteen years. However, our analysis does not support this claim. As China becomes stronger, realists generally expect Japan to undertake more vigorous balancing, but it has not done so. The stasis or even improvement of Sino-Japanese relations contradicts the realist prediction.

One implication of the discussion thus far is to recognize once again the limits of theory-realist in this case-in predicting and explaining complex real-world phenomena. Yet, the nondeterministic nature of some assumptions that make up the core of this vast research program are well known - an awareness that has often come about as the result of intense scholarly debate and conceptual development (e.g., Levy 2004; Paul 2004; Schweller 2004). Sometimes this debate has even been conducted with direct reference to the security situation in East Asia (Kang 2003-2004; Ross 2006; Chan 2010). For the purposes of this article, an equally important implication is to remind analysts of Japanese foreign and security policy, Sino-Japanese relations, and international politics in Northeast Asia about the limitations of balancing theory, which many seem to take for granted and use rather unreflectingly.

If one believes that states automatically balance against rising power, one clearly risks missing what has arguably been an enduring feature of Sino-Japanese relations post-1978-namely, Tokyo going along with China's interests and thereby accommodating the Chinese grand strategy and facilitating China's rise. This furthermore implies that little of the tension that has occurred in the Sino-Japanese relationship thus far has revolved around, or negatively affected, the core interests laid down in the Chinese grand strategy. Although some Japanese policymakers readily voice their apprehension of a more powerful China, Japan's policymaking apparatus as a whole has not acted as if China's rise were a threat. This, in turn, would also seem to project an image of a far less strained bilateral relationship and an overall lesser risk of bilateral conflict than what is customary-unless, of course, exaggerated fears of bilateral tension were themselves to produce or enhance the spiraling dynamics of a security dilemma. The fact that fear of conflict in East Asia presents the United States with a compelling 
reason to maintain its regional military presence is also interesting to note in conjunction with the fact that so much of the scholarship and policy analysis that reproduces this fear originates in the United States. ${ }^{9}$

Japanese accommodation vis-à-vis China has continued more or less independently of the ups and downs that have otherwise characterized the political relationship between the two countries. Yet, this trajectory cannot necessarily be projected into the future. Tokyo's increased apprehension of China's military development and the bilateral tensions that erupted after a Chinese trawler collided with a Japanese coastguard patrol boat in September 2010 were arguably reflected in the latest update of the NDPG and the shift of military weight from Hokkaido to the Nansei Islands. At the same time, these reforms in themselves hardly represent a shift toward internal balancing.

We did not set out in this article to explain the interests or intentions behind Japan's China policy, but we do raise a number of questions with an explanatory purpose, to be pursued in future research: What explains Japan's accommodation of the rise of China post-1978? How should intermittent tensions in the relationship be understood in light of this overall tendency? Finally, do the recent developments, summarized in the preceding paragraph, signify the beginning of a new Japanese containment policy, and if so, why are they occurring now?

Björn Jerdén is a PhD candidate in the Department of Political Science, Stockholm University, and research associate at the Swedish Institute of International Affairs. $\mathrm{He}$ is writing his thesis on contemporary international relations in Northeast Asia and has previously published in Pacific Affairs. His research is supported by a grant from Torsten and Ragnar Söderberg's foundations.

Linus Hagström is associate professor of political science and senior research fellow at the Swedish Institute of International Affairs. He is also research fellow at the Royal Swedish Academy of Letters, History, and Antiquities where his work is supported by a grant from the Knut and Alice Wallenberg Foundation. Hagström is currently a Japan Foundation Fellow at Kyoto University and is the author of Japan's China Policy: A Relational Power Analysis. His research has recently been published in the Australian Journal of International Affairs, Pacific Affairs, Asian Survey, and Asian Security.

\section{Notes}

For excellent comments on previous drafts of this article we would like to extend our gratitude to two anonymous reviewers of JEAS as well as to Steve Chan, Magnus Ericson, Karl Gustafsson, Stephan Haggard, Kimie Hara, Chris Hughes, Masaya Inoue, Matthew Linley, Scott McIver, James Manicom, Paul Midford, and Tom Wilkins. We would also like to thank John Swenson-Wright, 
Barak Kushner, Mitch Sedgwick, Tosh Minohara, and Caroline Rose for hosting presentations based on previous versions of the article at the universities of Cambridge, Oxford Brookes, Kobe, and Leeds.

1. Some were admittedly alarmed by Japan's postwar rise as well (e.g., Friedman and Lebard 1991).

2. "Western" and "the West" are used throughout to describe the AngloSaxon countries, Western Europe, and Japan.

3. This framework is inspired by, but still distinct from, the overview of China's foreign policy proposed in Hart (2008).

4. Hagström's interview with Matsubara Jin, Democratic Party of Japan (DPJ) Diet member, Tokyo, December 7, 2010.

5. The Dalai Lama formally resigned from his political responsibilities within the Tibetan government in exile in March 2011.

6. At the Foreign Relations Committee of the House of Representatives on March 26, 2008, lawmaker Shinohara Takashi (DPJ) referred to a meeting between former prime minister Ohira Masayoshi and the Dalai Lama: "Historically speaking, Ohira Masayoshi met [with the Dalai Lama] only once," but Foreign Minister Komura Masahiko neither confirmed nor corrected the statement (see Kokkai kaijiroku kensaku shisutemu). However, we have not been able to confirm that this meeting took place. A set of electronic documents (Masayoshi Ohira Memorial Foundation 2001), which chronologically records Ohira's actions in detail during his tenure as prime minister (1978-1980), covers such details as whom Ohira played golf with and when, but does not seem to contain any specific reference to his possible meeting with the Dalai Lama. A Japanese career diplomat speculates in personal correspondence with the authors that this might indicate that Ohira did meet with the Dalai Lama, but on the condition that the meeting should be regarded as having never taken place. The diplomat suspects that the meeting turned out to be too sensitive in relation to the PRC to be mentioned openly.

7. We thank Robert S. Ross for pointing this out. 2008).

8. Arguably, neither have many of the other parties involved (see Hagström

9. Examples of this kind of scholarship include seminal pieces by Betts (1993) and Friedberg (1993).

\section{References}

Arase, David. 1993. "Japanese Policy Toward Democracy and Human Rights in Asia." Asian Survey 33, 10: 935-952.

2007. "Japan, the Active State? Security Policy After 9/11." Asian Survey 47, 4: 560-583.

Betts, Richard K. 1993. "Wealth, Power, and Instability: East Asia and the United States After the Cold War." International Security 18, 3: 34-77.

Chan, Steve. 2010. "An Odd Thing Happened on the Way to Balancing: East Asian States' Reactions to China's Rise." International Studies Review 12, 3: 387-412. 
Chen, Jian. 1996. "Understanding the Logic of Beijing's Taiwan Policy.” Security Dialogue 27, 4: 459-462.

Chung, Jae Ho. 2009. "East Asia Responds to the Rise of China: Patterns and Variations." Pacific Affairs 82, 4: 657-675.

Deng, Xiaoping. 1994a. Selected Works of Deng Xiaoping: Volume II (19751982). Beijing: Foreign Languages Press.

- 1994b. Selected Works of Deng Xiaoping: Volume III (1982-1992). Beijing: Foreign Languages Press.

Deng, Yong. 1997. "Chinese Relations with Japan: Implications for AsiaPacific Regionalism.” Pacific Affairs 70, 3: 373-391.

— 2006. "Reputation and the Security Dilemma: China Reacts to the China Threat Theory." In New Directions in the Study of China's Foreign Policy, ed. Alastair Iain Johnston and Robert S. Ross. Stanford: Stanford University Press.

- 2008. China's Struggle for Status: The Realignment of International Relations. New York: Cambridge University Press.

Doi, Kanae. 2010. "Human Rights Should Be Kan's Foreign Policy Priority." Human Rights Watch. Available at www.hrw.org/en/news/2010/08/02 /human-rights-should-be-kans-foreign-policy-priority.

Drifte, Reinhard. 2003. Japan's Security Relations with China Since 1989: From Balancing to Bandwagoning? London and New York: RoutledgeCurzon.

- 2006. "The Ending of Japan's ODA Loan Programme to China-All's Well that Ends Well?" Asia-Pacific Review 13, 1: 94-117.

Fisher, Richard D., Jr. 2008. China's Military Modernization: Building for Regional and Global Reach. Westport, CT: Praeger Security International.

Fravel, Taylor M. 2008. Strong Borders, Secure Nation: Cooperation and Conflict in China's Territorial Disputes. Princeton: Princeton University Press.

Friedberg, Aaron L. 1993. "Ripe for Rivalry: Prospects for Peace in a Multipolar Asia." International Security 18, 3: 5-33.

Friedman, George, and Meredith Lebard. 1991. The Coming War with Japan. New York: St. Martin's Press.

Fuchs, Andreas, and Nils-Hendrik Klann. 2010. "Paying a Visit: The Dalai Lama Effect on International Trade.” Research Paper No. 113. Göttingen: Center for European Governance and Economic Development.

Fujimura, Osamu. 2011. "Press Conference by the Chief Cabinet Secretary," November 8. Available at www.kantei.go.jp/foreign/tyoukanpress/2011 11/111108_0951.html.

Fukushima, Akiko. 2009. "Japan's Perspective on Asian Regionalism." In Asia's New Multilateralism: Cooperation, Competition and the Search for Community, ed. Michael J. Green and Bates Gill. New York: Columbia University Press.

Gill, Bates. 2007. Rising Star: China's New Security Diplomacy. Washington, DC: Brookings Institution Press. 
Goh, Evelyn. 2006. "Understanding 'Hedging' in Asia-Pacific Security." PacNet 43 (August 31).

Goldstein, Avery. 2005. Rising to the Challenge: China's Grand Strategy and International Security. Stanford: Stanford University Press.

Grieco, Joseph M. 1988. "Anarchy and the Limits of Cooperation: A Realist Critique of the Newest Liberal Institutionalism." International Organization 42, 3: 485-507.

Gustafsson, Karl. 2011. "Narratives and Bilateral Relations: Rethinking the 'History Issue' in Sino-Japanese Relations." PhD diss., Department of Political Science, Stockholm University.

Hagström, Linus. 2005a. Japan's China Policy: A Relational Power Analysis. London: Routledge.

- 2005b. "Quiet Power: Japan's China Policy in Regard to the Pinnacle Islands." Pacific Review 18, 2: 159-188.

. 2008. "Critiquing the Idea of Japanese Exceptionalism: Japan and the Coordination of North Korea Policy." European Journal of East Asian Studies 7, 1: 131-154.

- 2008-2009. "Sino-Japanese Relations: The Ice That Won't Melt." International Journal 64, 1: 223-240.

— 2009. "Normalizing Japan: Supporter, Nuisance, or Wielder of Power in the North Korean Nuclear Talks." Asian Survey 49, 5: 831-851.

- Forthcoming 2012. "Power Shift in East Asia? A Critical Reappraisal of the Diaoyu/Senkaku Islands Incident in 2010." Chinese Journal of International Politics.

Hagström, Linus, and Björn Jerdén. 2010. "Understanding Fluctuations in Sino-Japanese Relations: To Politicize or to De-politicize the China Issue in the Japanese Diet." Pacific Affairs 83, 4: 719-739.

Hagström, Linus, and Christian Turesson. 2009. "Among Threats and a 'Perfect Excuse': Understanding Change in Japanese Foreign Security Policy.” Korean Journal of Defense Analysis 21, 3: 297-314.

Hagström, Linus, and Jon Williamsson. 2009. "'Remilitarization,' Really? Assessing Change in Japanese Foreign Security Policy." Asian Security 5, 3: 242-272.

Hart, Tom. 2008. "Looking Back and Looking Forward: A Broad-Brush Evaluation and Critique of the Chinese Foreign Policy Evolution." In China Rising: Reactions, Assessments, and Strategic Consequences, ed. Bo Huldt et al. Stockholm and Helsinki: Swedish National Defence College/Finnish National Defence University.

He, Yinan. 2008. "Ripe for Cooperation or Rivalry? Commerce, Realpolitik, and War Memory in Contemporary Sino-Japanese Relations." Asian Security 4, 2: 162-197.

Heazle, Michael, and Nick Knight. 2007. "Introduction: 2005-China and Japan's Year of Living Dangerously." In China-Japan Relations in the Twenty-First Century: Creating a Future Past? ed. Michael Heazle and Nick Knight. Cheltenham: Edward Elgar.

Heginbotham, Eric, and Richard J. Samuels. 2002. "Japan's Dual Hedge.” Foreign Affairs 81, 5: 110-121. 
Hilpert, Hanns Günther, and Katsuji Nakagane. 2002. "Economic Relations: What Can We Learn from Trade and FDI?" In Chinese-Japanese Relations in the Twenty-first Century, ed. Marie Söderberg. London: Routledge.

Hongo, Jun. 2009. “Step Up to Plate, Dalai Lama Envoy Tells Japan.” Japan Times. Available at http://search.japantimes.co.jp/cgi-bin/nn20090521a3.html.

Hsiung, James C. 2007. "Introduction: Theory and the Long-Running Tussle." In China and Japan at Odds: Deciphering the Perpetual Conflict, ed. James C. Hsiung. Basingstoke: Palgrave Macmillan.

Hu, Shaohua. 2006. "Japan and the Cross-Taiwan Strait Conflict." Journal of Chinese Political Science 11, 2: 83-103.

$\mathrm{Hu}$, Zongshan. 2005. "Heping jueqi shifou keneng? Lishi yu lilun de sikao" [Is peaceful rise possible? Historical and theoretical reflections]. Journal of Yunyang Teachers College 25, 4.

Hughes, Christopher W. 2009. "Japan's Military Modernisation: A Quiet JapanChina Arms Race and Global Power Projection." Asia-Pacific Review 16, 1: 84-99.

Hughes, Christopher W., and Ellis S. Krauss. 2007. "Japan's New Security Agenda." Survival 49, 2: 157-176.

International Monetary Fund (IMF). 1985, 1992, 1998, 2003, 2007, 2010. Direction of Trade Statistics Yearbook. Washington, DC: IMF.

Japan National Defense Program Guidelines, FY 2011 and beyond. Available at www.kantei.go.jp/jp/kakugikettei/2010/1217boueitaikou.pdf.

Jin, Xide. 2007. 21shiji de Zhong Ri Guanxi [Sino-Japanese relations of the 21st century]. Chongqing: Chongqing Publishing House.

- 2008. "Zhongguo gaige kaifang 30nian yu Riben duihua ODA" [30 Years of China's reform and opening-up and Japanese ODA to China]. Jiaoxиe yи yanjiu [Teaching and research] 11: 21-24.

Johnston, Alastair Iain. 2004. "China's Militarized Interstate Dispute Behaviour 1949-1992: A First Cut at the Data." In Chinese Foreign Policy in Transition, ed. Liu Guoli. New York: Aldine de Gruyter.

Joint Communiqué of the Government of Japan and the Government of the People's Republic of China September 29, 1972. Available at www.mofa .go.jp/region/asia-paci/china/joint72.html.

Kang, David. 2003-2004. "Hierarchy, Balancing, and Empirical Puzzles in Asian International Relations." International Security 28, 3: 165-180.

- 2007. China Rising: Peace, Power, and Order in East Asia. New York: Columbia University Press.

Katada, Saori. 2001. "Why Did Japan Suspend Foreign Aid to China? Japan's Foreign Aid Decision-making and Sources of Aid Sanction." Social Science Japan Journal 4, 1: 39-58.

Kennedy, Paul. 1989. The Rise and Fall of the Great Powers: Economic Change and Military Conflict from 1500 to 2000. London: Fontana Press. 1991. "Grand Strategy in War and Peace: Toward a Broader Definition." In Grand Strategies in War and Peace, ed. Paul Kennedy. New Haven: Yale University Press.

Kesavan, K. V. 1990. "Japan and the Tiananmen Incident: Aspects of the Bilateral Relationship." Asian Survey 30, 7: 669-681. 
Kokkai kaijiroku kensaku shisutemu [A search system for Diet protocols]. Available at http://kokkai.ndl.go.jp.

Kyodo. 2000. "Japan Warned Dalai Lama Not to Meet Ishihara." Available at www.tibet.ca/en/newsroom/wtn/archive/old? $y=2000 \& m=4 \& p=16 \_2$.

Layne, Christopher. 1993. "The Unipolar Illusion: Why New Great Powers Will Rise." International Security 17, 4: 5-51.

Lebow, Richard Ned. 1994. "The Long Peace, the End of the Cold War, and the Failure of Realism." International Organization 48, 2: 249-277.

Legro, Jeffery W. 2005. Rethinking the World: Great Power Strategies and International Order. Ithaca: Cornell University Press.

—. 2008. "Purpose Transitions: China's Rise and the American Response." In China's Ascent: Power, Security, and the Future of International Politics, ed. Robert S. Ross and Zhu Feng. Ithaca: Cornell University Press.

Legro, Jeffery W., and Andrew Moravcsik. 1999. "Is Anybody Still A Realist?" International Security 24, 2: 5-55.

Levy, Jack S. 2004. "What Do Great Powers Balance Against and When?" In Balance of Power: Theory and Practice in the 21st Century, ed. T. V. Paul, James J. Wirtz, and Michel Fortmann. Stanford: Stanford University Press.

Lin, Zhibo. 2005. "Dangdai zhongguo xuyao minzuzhuyi: jianlun zhongriguanxi" [Contemporary China needs nationalism: On the Sino-Japan relationship]. Zhongguo yu shijie guancha [China and world affairs] 1 (October).

Lind, Jennifer M. 2004. "Pacifism or Passing the Buck? Testing Theories of Japanese Security Policy." International Security 29, 1: 92-121.

Masayoshi Ohira Memorial Foundation [Ohira Masayosi Kinen Zaidan]. 2001. Ohira Masayoshi Zen-Chosaku oyobi Kenkyu-sho [All writings of Ohira Masayoshi and research papers].

Mearsheimer, John J. 1994-1995. "The False Promise of International Institutions." International Security 19, 3: 5-49.

- 2001. The Tragedy of Great Power Politics. New York: Norton.

- 2006. “China's Unpeaceful Rise." Current History 105, 690: 160-162.

Men, Honghua. 2008. "Zhongguo jueqi yu anquan zhixu de biange" [China's rise and the transformation of the security order]. Guoji guancha [International review] 92, 2: 16-25.

Ministry of Foreign Affairs of Japan. 1978. "Treaty of Peace and Friendship Between Japan and the People's Republic of China." Available at www.mofa.go.jp/region/asia-paci/china/treaty78.html.

Mochizuki, Mike M. 2007. "Japan's Shifting Strategy Toward the Rise of China." Journal of Strategic Studies 30, 4-5: 739-776.

Naughton, Barry. 2007. The Chinese Economy: Transitions and Growth. Cambridge: MIT Press.

Noble, Gregory W. 2005. "What Can Taiwan (and the United States) Expect from Japan." Journal of East Asian Studies 5, 1: 1-34.

Odgaard, Liselotte. 2008. "Chinese Northeast Asia Policies and the Tragedy of Northeast Asia's Security Architecture." Global Change, Peace and Security 20, 2: 185-199. 
OECD (Organization for Economic Cooperation and Development). 2010a. "Aggregate Aid Statistics: ODA by Recipient by Country." OECD International Development Statistics (database), doi: 10.1787/data-00064-en.

- 2010b. "Foreign Direct Investment: Flows by Partner Country." OECD International Direct Investment Statistics (database), doi: 10.1787/data-00335-en.

Oros, Andrew L. 2007. "The Domestic and International Politics of Constitutional Change in Japan." Education About Asia 12, 3: 39-44.

- 2008. Normalizing Japan: Politics, Identity and the Evolution of Security Practice. Stanford: Stanford University Press.

Paul, T. V. 2004. "Introduction: The Enduring Axioms of Balance of Power Theory and Their Contemporary Relevance." In Balance of Power: Theory and Practice in the 21st Century, ed. T. V. Paul, James J. Wirtz, and Michel Fortmann. Stanford: Stanford University Press.

Pearson, Margaret M. 2001. "The Case of China's Accession to GATT/WTO." In The Making of Chinese Foreign Security Policy in the Era of Reform, ed. David M. Lampton. Stanford: Stanford University Press.

Posen, Barry P. 1984. The Sources of Military Doctrine: France, Britain, and Germany Between the World Wars. Ithaca: Cornell University Press.

Pyle, Kenneth. 2007. Japan Rising. New York: PublicAffairs.

Repp, Martin. 2008. "H.H. The 14th Dalai Lama and the Japanese Buddhists: An Account and Analysis of Complicated Interactions." Japanese Religions 33, 1-2: 103-125.

Ross, Madelyn C. 1994. "China's International Economic Behaviour." In Chinese Foreign Policy: Theory and Practice, ed. Thomas W. Robinson and David L. Shambaugh. Oxford: Oxford University Press.

Ross, Robert S. 2005. "Assessing the China Threat." National Interest (Fall): $81-87$.

- 2006. "Balance of Power Politics and the Rise of China: Accommodation and Balancing in East Asia." Security Studies 15, 3: 355-395.

Ross, Robert S., and Zhu Feng. 2008. "The Rise of China: Theoretical and Policy Perspectives." In China's Ascent: Power, Security, and the Future of International Politics, ed. Robert S. Ross and Zhu Feng. Ithaca: Cornell University Press.

Samuels, Richard J. 2006. "Japan's Goldilocks Strategy.” Washington Quarterly 29, 4: 111-127.

Sasaki, Tomonori. 2010. "China Eyes the Japanese Military: China's Threat Perception of Japan Since the 1980s." China Quarterly 203: 560-580.

Sato, Yoichiro. 2009. "Tango Without Trust and Respect? Japan's Awkward CoProsperity with China in the Twenty-First Century." In The Rise of China and International Security: America and Asia Respond, ed. Kevin J. Cooney and Sato Yoichiro. New York: Routledge.

Schweller, Randall L. 1994. "Bandwagoning for Profit: Bringing the Revision-

ist State Back In." International Security 19, 1: 72-107. Engaging China: The Management of an Emerging Power, ed. Alastair Iain Johnston and Robert S. Ross. New York: Routledge. 
2004. "Unanswered Threats: A Neoclassical Realist Theory of Underbalancing." International Security 29, 2: 159-201.

Shambaugh, David L. 2004-2005. "China Engages Asia: Reshaping the Regional Order.” International Security 29, 3: 64-99.

Shinoda, Tomohito. 2007. "Becoming More Realistic in the Post-Cold War: Japan's Changing Media and Public Opinion on National Security." Japanese Journal of Political Science 8, 2: 171-190.

Tanaka, Akihiko. 1991. Nitchu kankei, 1945-1990 [Japan-China relations, 1945-1990]. Tokyo: Tokyo Daigaku Shuppankai.

- 2007. Ajia no naka no Nihon [Japan in Asia]. Tokyo: NTT Shuppan.

Tipton, Frank B., and Huilin Xiao. 2006. "China.” In Japanese Official Development Assistance in the Asian Region: Building Institutional Capacity in Asia 2005-06. Sydney: Research Institute for Asia and the Pacific, in association with the Japanese Ministry of Finance.

Tsang, Steve. 2008. "China's Grand Strategy and Its Rise." In China Rising: Reactions, Assessments, and Strategic Consequences, ed. Bo Huldt et al. Stockholm and Helsinki: Swedish National Defence College/Finnish National Defence University.

Walt, Stephen M. 1987. The Origin of Alliances. Ithaca: Cornell University Press. Waltz, Kenneth N. 1979. Theory of International Politics. New York: McGrawHill.

- 1993. "The Emerging Structure of International Politics." International Security 18, 2: 44-79.

- 2000. "Structural Realism After the Cold War." International Security 25, 1: 5-41.

Wu, Xinbo. 2009. "China's Perspectives on Building an East Asian Community in the Twenty-first Century." In Asia's New Multilateralism: Cooperation, Competition and the Search for Community, ed. Michael J. Green and Bates Gill. New York: Columbia University Press.

Xinhuanet. 2005. "Beijing Opposes US-Japan Statement on Taiwan." Available at http://news.xinhuanet.com/english/2005-02/20/content_2596291.htm.

Yan, Xuetong. 2006. "The Rise of China and Its Power Status." Chinese Journal of International Politics, 1, 1: 5-33.

Zhang, Dong Dong. 1998. "Negotiating for a Liberal Economic Regime: The Case of Japanese FDI in China." Pacific Review 11, 1: 51-78.

Zhao, Quansheng. 2006. "Chinese North Korea Policy: A Secondary Role for Japan." In North Korea Policy: Japan and the Great Powers, ed. Linus Hagström and Marie Söderberg. London: Routledge.

Zheng, Bijian. 2005. "China's 'Peaceful Rise' to Great-Power Status." Foreign Affairs 84, 5: 18-24. 